\title{
A new IUGS Commission for Geoheritage: The 'ICG'
}

\author{
Dolores Pereira ${ }^{1 *}$, and Kevin Page ${ }^{2}$ \\ ${ }^{1}$ Department of Geology, Plaza de la Merced s/n, University of Salamanca, 37008 Salamanca, Spain; Secretary General of the Heritage Stone \\ Subcommission; *Corresponding autor,E-mail: mdp@usal.es \\ ${ }^{2}$ School of Geography, Earth and Environmental Science, Plymouth University, Drake Circus, Plymouth PL4 8AA United Kingdom; Secre- \\ tary General of the Geoheritage Sites and Collections Subcommission; E-mail: kevin.page@plymouth.ac.uk
}

2016 marked a milestone in the development of the principles and practice of Geodiversity, Geoheritage and related conservation through the establishment of IUGS's new International Commission on Geoheritage (ICG) at the $35^{\text {th }}$ International Geological Congress in Cape Town (29 $9^{\text {th }}$ August to $2^{\text {nd }}$ September 2016). This broad subject is fundamental to society's interaction with the geological sciences, as it concerns all aspects of geological materials and processes, both in a natural and a cultural context and their intrinsic importance for a great range of human activities, including research, education, outreach, cultural value, sustainable development and as part of a shared natural and cultural heritage to be safeguarded for future generations. The establishment of ICG enables the Union to take a true leadership role in this rapidly developing field, including providing a much needed umbrella for the development of geoheritage-related principles, practice and standards globally. Crucially, the Commission can also provide a source of expertise within IUGS, as it advises both external global networks and programmes related to geodiversity and geoheritage such as UNESCO (including in relation to Global Geoparks and geological heritage World Heritage sites) and the International Union for the Conservation of Nature (IUCN), as well as issues related to the development of global listings of Geosites, which would include all Global Stratotype Section and Point (GSSP) sites, and characterization of natural stones for construction and preservation purposes.

\section{Origins}

The origins of the Commission lie in the establishment of the Heritage Stone Task Group (HSTG) and the Geoheritage Task Group (GTG) at the 33th International Geological Congress in Oslo, Norway, in 2008. At the same meeting, the HSTG also established the concept of Global Heritage Stone Resource (GHSR) as a step towards improving the knowledge of natural stones that have a historical use. The initiative established a formal international geological designation for important types of natural stone that have been widely used and/or have widespread cultural and architectural recognition (Cooper et al. 2013). The Geoheritage Task Group (GTG) mission included coordinating the many global programmes dealing with recognition, conservation, education and protection of geological heritage. This Task Group was created to assist in identifying and promoting important geosites, Geoparks, World Heritage sites, and other globally significant sites recognised for their geologic values. More than 360 sites have been described already, with information on legislation, GIS, etc... that is already present in its web page.

As the links between geological materials in a cultural context, for instance building stones, and a natural situation, for instance in a quarry, and the aims of both Task Groups include the conservation of such materials in their natural context, it was only logical to establish a per- manent link between task groups. This was established within the IUGS Executive Committee at its annual meeting in Kunming, China, in January 2016, where a joint action to merge both task groups into a new IUGS commission on Geoheritage was proposed and was formally ratified by IUGS Council in South Africa.

\section{The new Commission and future activities}

The new Commission comprises two subcommissions, which will continue to develop the activities of the original Task Groups, specifically the Heritage Stones Subcommission (HSS) and the Heritage Sites and Collections Subcommission (HSCS). The Commission has a Chair (Björn Schouenborg) and Secretary General (Kevin Page) and each Subcommission has its own Chair and Secretary (Björn Schouenborg and Lola Pereira, respectively, for the HSRS, and Patrick De Wever and Kevin Page, respectively, for the HSCS). The Chair and Secretary General of each Subcommission, forming the Board of the IUGS International Commission on GeoHeritage, will alternate as Commission Chair and Secretary General for a 2 year period. When the Chair is elected from the HSS, the Secretary General is elected from the HSCS and vice versa.

As with other IUGS Commissions and Subcommissions, it is proposed that much of the envisaged work of the Subcommissions could be carried out by thematic working groups or the convenient members of the board of each Subcommission. The establishment of such groups and boards would be subject to approval by the respective Subcommission, and they will report back to the Subcommission, and hence the Commission, annually, or when seeking formal approval or support for any proposals from the board of the Subcommission and the Commission. Terms of Reference of the Commission specify these procedures.

\section{Future steps}

The initial challenge for the Commission is to establish formal links with other organisations and programmes working on the broad field of Geodiversity and Geoheritage and its links to culture and the built environment. Initial contact with key players and potential partners on the global stage has been very positive and it is hoped that these will soon transform into close working associations. In addition, discussions are already taking place regarding the establishment of thematic working groups for the HSCS to provide a formal structure within which to develop important facets of policy and practice at a global level. A new board was negotiated for the HSS, with members representing countries with a significant heritage stone patrimony.

Crucially, however, the Commission needs to enable partners, practitioners and any other interested parties to meet, discuss concepts and present results. In this context, the highly successful sessions at the 
$34^{\text {th }}$ IGC in Brisbane, Australia, and the $35^{\text {th }}$ IGC in Cape Town provide a model of the primary context for such meetings at a global scale. Key regional meetings, such as that of the EGU (European Geological Union) have also provided a very successful context for sessions on Heritage Stones and Geoheritage, in addition, of course, to the cycle of specifically geoheritage-themed congresses of the European Association for the Conservation of the Geological Heritage, ProGEO, and others (Cornée et al. 2016).

The use of both Subcommissions websites (http://globalheritagestone.com/ and http://geoheritage-iugs.mnhn.fr/) will allow the dissemination of news and information about the activities of both subcommissions. Formal publication of key advances and policies will be possible through a range of international journals and other publications, including Episodes (http://www.episodes.org/) and Geoheritage (www.springer.com/12371), the latter been specifically dedicated to geosites and collections.

But the challenge is now on to ensure that the dynamic progress of both the Heritage Stone and Geoheritage task groups is translated into the structure of the new Commission and we really do begin to develop and influence global policy and practice in this exciting new field, which provides the strongest of connections between society and the geosciences!

\section{Acknowledegments}

The new Commission acknowledges the continuous support of the IUGS as well as the International Geoscience Program (IGCP) 637 project for partially funding some of the Heritage Stone meetings. Peter Bobrowsky helped in the edition of this report.

\section{References}

Cooper, B., Marker, B., Pereira, D., and Schouenborg, B., 2013, Establishment of the "Heritage Stone Task Group" (HSTG): Episodes, v.36, no.1, pp. 8-10.

Cornée, A., Egoroff, G., De Wever, P., Lalanne, A., and Duranthon, F. (eds.), 2016, Actes du congrès international « Les inventaires du géopatrimoine », 22-26 septembre 2015, Toulouse. Mém. H.S. Soc. Géol. Fr., 16, 368 p.

Pereira, D., and Baltuille, J.M., 2014, Documenting natural stone to preserve our cultural and architectonic heritage: Materiales de Construcción, 64-314, Editorial.

Pereira, D., and González Neila, C., 2015, The Global Heritage Stone Province concept, in Douet, J., ed., European Quarry Landscapes, LIFE Project, pp. 47-52. 